Creative Commons User License: CC BY-NC-ND

Abstracted by: EBSCOhost, Electronic Journals Service (EJS),

Google Scholar, Journal Seek, Scientific Commons,

Food and Agricultural Organization (FAO), CABI and Scopus

http://eoi.citefactor.org/10.11226/v26i1
Journal of Agricultural Extension

Vol. 26 (1) January, 2022

ISSN(e): 24086851; ISSN(Print); 1119944X

http://journal.aesonnigeria.org

http://www.ajol.info/index.php/jae

Email: editorinchief@aesonnigeria.org

\title{
Benefits of the West Africa Agricultural Productivity Programme on Fisherfolks in Kainji Lake Basin, Nigeria \\ https://dx.doi.org/10.4314/jae.v26i1.1
}

\section{Faleke, Sunday Akinola}

Extension Programme, National Institute for Freshwater Fisheries Research (NIFFR), P.M.B. 6006, New Bussa, Nigeria

Email: falekesunday12@gmail.com; Phone: +2347066419500

\section{Nwabeze, Godfrey Onyekachukwu}

Extension Programme, National Institute for Freshwater Fisheries Research (NIFFR), P.M.B. 6006, New Bussa, Nigeria

Email: onyegodfrey@yahoo.com; Phone: +2348052923218

\section{Buhari Habeeb Lola}

Basic Science Department, Federal college of Freshwater Fisheries Technology (FCFFT), P.M.B. 1500, New Bussa, Nigeria

Email: lollybury@yahoo.com; Phone: +2348068869830

\begin{abstract}
The study assessed the benefits of West Africa Agricultural Productivity Programme (WAAPP) through inputs, training and services received; attitude; satisfaction; and constraints of respondents in WAAPP. Four National Institute for Freshwater Fisheries Research (NIFFR) adopted villages were selected purposively, namely; Monai, Mussawa, Tunga Alhaji Dambaba, and Cover Dam out of eight established villages due to large number of WAAPP activities in the area. The total number of respondents sampled in selected adopted villages was 120. Data collected were analysed using percentage, standard deviation and mean. Results of the study revealed that the majority (88.2\%) of the respondents received improved fingerlings and fish feeds from WAAPP and $67.7 \%$ of the respondents had favourable attitude towards the programme. About 59\% were favourably satisfied, and $56 \%$ derived high level of benefit from the programme. About $47 \%$ were severely constrained by inadequate capital to sustain the programme projects.
\end{abstract}

Keywords: Poverty; productivity; adopted; village and programme

\section{Introduction}

Aquaculture can be a driver for rural development with the objectives of mitigating risks to livelihoods, improving nutrition, contributing to income generation, poverty alleviation and employment (Babatunde, Deborah, Gan and Simon 2021). Rural areas are characterized by low income, poverty, malnutrition, poor health, poor education, inadequate infrastructure among others. Despite rural people working around the clock day and night to meet their basic needs, their income still very low (Josef and Jiri 2019), especially as the income of fisher folks depend on seasons and nature (Teddy, 2017). Many poverty alleviation programmes and interventions have been initiated to solve these problems where some have yielded positive result 
Creative Commons User License: CC BY-NC-ND

Abstracted by: EBSCOhost, Electronic Journals Service (EJS), Google Scholar, Journal Seek, Scientific Commons,

Food and Agricultural Organization (FAO), CABI and Scopus
Journal of Agricultural Extension

Vol. 26 (1) January, 2022

ISSN(e): 24086851; ISSN(Print); 1119944X

http://journal.aesonnigeria.org

http://www.ajol.info/index.php/iae

Email: editorinchief@aesonnigeria.org

while others failed. Christian (2020) reported that over the years, successive governments in Nigeria have attempted to address these problems through various programmes, initiatives and policies. This is also supported by George, (2017) that, National Development plans of Nigeria from 1975-1985 and other rural development programmes like the Operation Feed the Nation (OFN), Green Revolution, River Basin Development Authorities, Agricultural Development Projects and many others have emphasized the need to tackle the problem of rural under-development. Every government in Nigeria up to present regime had set up various development programmes with the aim of bringing lasting solution to problems endemic to rural development in which few of them are on-going, some are short lived and others have gone with the regimes that initiated them (Obeta and Chukwudike, 2020). This has led to the poor development of rural area despite huge financial, human and material resources utilized. Obiero, Waidbacher, Nyawanda, Bryan, Jonathan, Julius and Boaz (2019) also asserted that many governments, development agencies and multilateral institutions/donors have promoted rural development through various assistance/intervention programmes for household food security, employment and poverty alleviation. Thus, with the implementation of these programmes at different levels in Nigeria, rural areas are still wallowing in abject poverty, they are underdeveloped despite the fact that the bulk of national economic development comes from them.

Therefore, the West Africa Agricultural Productivity Programme (WAAPP) as subregional programme of ECOWAS, funded mostly by the World Bank coordinated by the West and Central Africa Council for Agricultural Research Development (WECARD/CORAF), is mandated with the objective to increase agricultural productivity in the countries of the sub-region. The programme aims at providing conducive environment for Nigeria to cooperate with countries in the West African sub-region in technology generation and dissemination with a view to improving access of participating farmers to improved agricultural technologies and promote the culture of demand-driven technology generation and dissemination in the country using the value-chain approach (WAAPP, 2017). In particular, the project seeks to transform the National Institute for Freshwater Fisheries (NIFFR) into a National Centre of Specialization (NCOS) in Aquaculture for the benefit of the region. Since the inception of this programme NIFFR has been a major driver of WAAPP activities by executing many projects relating to their objectives in aquaculture. NIFFR Socioeconomics and Extension Division has Agricultural Research Outreach Centre as a programme whose responsibilities centre on demonstrating proven aquaculture technologies to farmers in adopted villages. Furthermore, facilitating rural microeconomic development through promotion of livelihood activities such as crop and livestock production in combination with fisheries. It has a number of activities in the following adopted villages as its outreach centres :Monai, Musawa, Tungan Alhaji Danbaba, Yankede, Malale, Cover dam, Dukia, Tungan Mairuwa, Tungan Nailo, Federal Government Girls' College (FGGC) New Bussa, Government Secondary School (GSS) New Bussa and Correctional Centres New Bussa (Omeje, Sule, and Aguihe 2020). Thus, many technologies such as solar tent, cooling box, water quality 
Creative Commons User License: CC BY-NC-ND

Abstracted by: EBSCOhost, Electronic Journals Service (EJS), Google Scholar, Journal Seek, Scientific Commons,

Food and Agricultural Organization (FAO), CABI and Scopus

http://eoi.citefactor.org/10.11226/v26i1
Journal of Agricultural Extension

Vol. 26 (1) January, 2022

ISSN(e): 24086851; ISSN(Print); 1119944X

http://journal.aesonnigeria.org

http://www.ajol.info/index.php/jae

Email: editorinchief@aesonnigeria.org

kits among others have been developed and disseminated to fish farmers in these villages.

The broad objective of the study was to investigate WAAPP's benefits to fisher folks in NIFFR adopted villages in Kainji Lake Basin, Nigeria. Specifically, the objectives were to;

- ascertain the inputs, training and services received by respondents from WAAPP

- ascertain respondents' attitude toward WAAPP

- determine respondents' level of satisfaction in WAAPP

- identify respondents' constraints in WAAPP

\section{Methodology}

The study was carried out in NIFFR adopted villages in Kainji Lake Basin, Nigeria. Kainji

Lake is situated between Latitude $9^{\circ} 50^{\prime}$ and $1^{\circ} 55^{\prime}$ North and Longitude $4^{\circ} 23^{\prime}$ and $4{ }^{\circ}$ 51' East. It represents the second most important inland fisheries source in Nigeria. The lake is formed by the damming of River Niger in 1968. Purposive selection of NIFFR adopted villages was used for the study (four adopted villages include: Monai, Mussawa, Tunga Alh. Dambaba, and Cover Dam, out of eight established adopted villages were selected at $50 \%$ ) due to large number of WAAPP activities in the area. Interview schedule administered to 170 respondents was used to obtain needed primary data for the study. Data collected were analysed descriptively and inferentially.

\section{Results and Discussion}

\section{Inputs Training and Services Received from WAAPP}

Figure 1 shows the inputs, training and services received by respondents. Most of the respondents indicated that they received inputs such as improved fingerlings $(88.2 \%)$, improved fish feeds $(88.2 \%)$, water quality kits $(82.4 \%)$, improved crop seeds $(73.5 \%)$ and cooling box $(67.6 \%)$ during the WAAPP programme. However, access to finance was poor as only $8.8 \%$ indicated that they received loan during WAAPP programme implementation. Results show that most of the respondents do not have access to loan which can affect the sustainability of the programme activities. More than half of the respondents indicated that they were trained on environmental safe guard $(58.8 \%)$, fish processing technique $(55.9 \%)$ and fish feed formulation (52.9\%). It can be inferred from the result of this study that respondents had received one or more inputs, training or services from WAAPP programme. The respondents were equipped with the skills to practice aquaculture and the inputs to start new livelihoods for the betterment of their lives and Nigeria at large. This shows that training for fish farmers is fundamental in aquaculture business especially in management and inputs usage. Ndem and Elom (2016), also report that fish farmer that acquire management skills in fish farming will use the skills to establish and manage a fish farm which will provide financial security. 


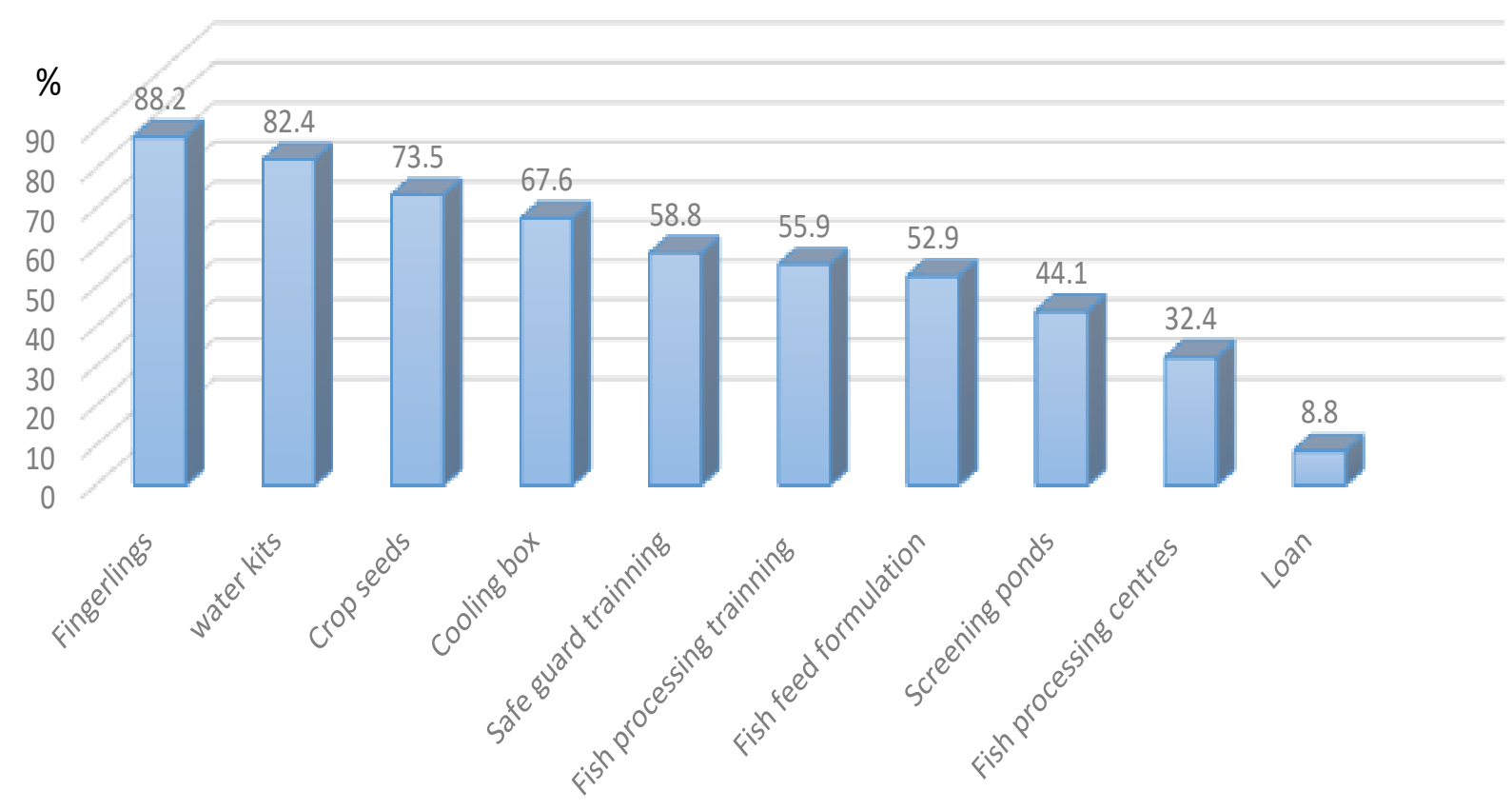

Figure 1: Inputs, training and services received

\section{Attitude towards WAAPP}

Table 1 shows respondents' disposition towards having no regret about participation in WAAPP $(\bar{x}=4.50)$ and could be attributed to the benefits accrued to the programme improving their productivity while they disagreed that WAAPP cannot improve their skills in fish production. It can be inferred that WAAPP exposes fisherfolk to various skills which could translate to improved productivity and wellbeing among others. Respondents were satisfied with the objectives of WAAPP $(\bar{x}=4.38)$, believe that their active participation in WAAPP could increase their production and productivity $(\bar{x}=4.38)$ and also considered WAAPP being a prerequisite to effective development in agricultural sector $(\bar{x}=4.35)$. This implies that the programme was highly participatory and respondents considered WAAPP as good programme that assisted them to acquire skills in developing themselves improving their productivity both in fisheries and other agricultural enterprises. This is supported by the work of Shibani (2016) and Nwabeze, Landu and Faleke (2019) that attitude and active participation of the people in the programme depend on the co-ordination, content and objectives of the programme that will avail them the privilege to share their experiences and also learn new knowledge and skills. The favourable disposition of fisherfolk to perception statements assessed is a good indication that WAAPP is beneficial to respondents. 
Creative Commons User License: CC BY-NC-ND

Abstracted by: EBSCOhost, Electronic Journals Service (EJS),

Google Scholar, Journal Seek, Scientific Commons,

Food and Agricultural Organization (FAO), CABI and Scopus
Journal of Agricultural Extension

Vol. 26 (1) January, 2022

ISSN(e): 24086851; ISSN(Print); 1119944X

http://journal.aesonnigeria.org

http://www.ajol.info/index.php/jae

Email: editorinchief@aesonnigeria.org

Table 1: Attitude towards WAAPP

\begin{tabular}{|c|c|c|}
\hline Statements & Mean* & SD \\
\hline $\begin{array}{l}\text { I have no regret about my participation in the WAAPP } \\
\text { programme }\end{array}$ & 4.50 & 0.84 \\
\hline The objectives of WAAPP programme are very good & 4.38 & 0.48 \\
\hline $\begin{array}{l}\text { Active participation in WAAPP program could increase the } \\
\text { production efficiency and productivity of the participants }\end{array}$ & 4.38 & 0.48 \\
\hline $\begin{array}{l}\text { WAAPP Programme is a pre-requisite to effective } \\
\text { development of agricultural sector }\end{array}$ & 4.35 & 0.41 \\
\hline $\begin{array}{l}\text { WAAPP Programme could improve welfare of the farming } \\
\text { population }\end{array}$ & 4.24 & 0.71 \\
\hline $\begin{array}{l}\text { WAAPP Programme can bring about changes in well-being of } \\
\text { participants }\end{array}$ & 4.18 & 0.83 \\
\hline $\begin{array}{l}\text { The programme is involve in dissemination of improved } \\
\text { technology }\end{array}$ & 4.06 & 0.97 \\
\hline $\begin{array}{l}\text { WAAPP Programme would ensure food/nutrition security } \\
\text { WAAPP Programme can help solve the production problems }\end{array}$ & 3.94 & 0.52 \\
\hline of participants & 3.71 & 0.67 \\
\hline $\begin{array}{l}\text { WAAPP Programme addressed the interest of the } \\
\text { implementers }\end{array}$ & 3.18 & $0-29$ \\
\hline $\begin{array}{l}\text { It is only the rich in the society that were targeted in WAAPP } \\
\text { programme }\end{array}$ & 2.94 & 0.52 \\
\hline $\begin{array}{l}\text { The WAAPP programme is not timely } \\
\text { WAAPP Programme does not address the felt needs of } \\
\text { farmers } \\
\text { The programme brings about decrease in yield rather than }\end{array}$ & $\begin{array}{l}2.91 \\
2.56 \\
2.32\end{array}$ & $\begin{array}{l}0.89 \\
1.34 \\
0.84\end{array}$ \\
\hline $\begin{array}{l}\text { increase } \\
\text { WAAPP Programme cannot improve the skills of farmers in } \\
\text { fish production } \\
\text { WAAPP Programme lacks commitment and focus }\end{array}$ & $\begin{array}{l}2.27 \\
2.24\end{array}$ & $\begin{array}{l}0.92 \\
0.74\end{array}$ \\
\hline $\begin{array}{l}\text { The WAAPP programme has not brought about positive } \\
\text { change to my income }\end{array}$ & 2.24 & 0.87 \\
\hline $\begin{array}{l}\text { The adaptive strategies taught in WAAPP were too hard } \\
\text { practice }\end{array}$ & 2.06 & 1.56 \\
\hline
\end{tabular}

Source: Field Survey, 2021, Agreed (mean $\geq 3.00$ )

\section{Satisfaction with WAAPP}

Table 2 indicates that respondents satisfaction with programme objectives $(\bar{x}=2.29)$ and adaptability $(\bar{x}=2.29)$ ranked highest, while cost implication of participants $(\bar{x}=1.85)$, programme mobilization ( $\bar{x}=1.88)$ and timeliness of $(\bar{x}=1.91)$ ranked least of the items on satisfaction. As explained by the respondents during the course of this field survey, they were aware and involved in the development process of WAAPP. It is paramount that sustainable programme should not only aim to 
Creative Commons User License: CC BY-NC-ND

Abstracted by: EBSCOhost, Electronic Journals Service (EJS), Google Scholar, Journal Seek, Scientific Commons,

Food and Agricultural Organization (FAO), CABI and Scopus
Journal of Agricultural Extension

Vol. 26 (1) January, 2022

ISSN(e): 24086851; ISSN(Print); 1119944X

http://journal.aesonnigeria.org

http://www.ajol.info/index.php/jae

Email: editorinchief@aesonnigeria.org

enlighten the beneficiaries, but it should also ensure the participation of the beneficiaries of such programme in the development process in order to bring about desirable change or action that affects them positively. This is collaborative with Olaleye (2019) assertion that community mobilization is the way in which people can be encouraged and motivated to participate in programme activities.

Table 2: Satisfaction of respondents with WAAPP

\begin{tabular}{|c|c|c|c|}
\hline Items & Mean* & SD & Rank \\
\hline Programme adaptability & 2.29 & 0.51 & $1^{\mathrm{st}}$ \\
\hline Programme objectives & 2.29 & 0.74 & $1^{\text {st }}$ \\
\hline Programme sensitization & 2.26 & 0.70 & $3^{\text {rd }}$ \\
\hline Flexibility of Programme & 2.26 & 0.53 & $3^{\text {rd }}$ \\
\hline Competence of facilitators & 2.24 & 0.54 & $5^{\text {th }}$ \\
\hline Teaching method & 2.21 & 0.47 & $6^{\text {th }}$ \\
\hline Contents of programme & 2.18 & 0.50 & $7^{\text {th }}$ \\
\hline Programme involvement & 2.18 & 0.74 & $7^{\text {th }}$ \\
\hline Conducive environment & 2.15 & 0.65 & $9^{\text {th }}$ \\
\hline Communication method & 2.12 & 0.81 & $10^{\text {th }}$ \\
\hline Compatibility of programme & 2.09 & 0.72 & $11^{\text {th }}$ \\
\hline $\begin{array}{l}\text { Planning programme with } \\
\text { beneficiaries }\end{array}$ & 2.03 & 0.57 & $12^{\text {th }}$ \\
\hline $\begin{array}{l}\text { Building of beneficiaries } \\
\text { capacity }\end{array}$ & 2.00 & 0.47 & $13^{\text {th }}$ \\
\hline Timeliness of programme & 1.91 & 0.72 & $14^{\text {th }}$ \\
\hline Programme mobilization & 1.88 & 0.72 & $15^{\text {th }}$ \\
\hline Cost implication of participants & 1.85 & 0.51 & $16^{\text {th }}$ \\
\hline
\end{tabular}

Source: Field Survey, 2021, Agreed (mean $\geq 2.00$ )

\section{Benefits Derived from WAAPP}

Table 3 shows that respondents benefit with programme advisory services $(\bar{x}=1.59)$ ranked first. Improvement in household food security $(\bar{x}=1.53)$, promotion of local skills $(\bar{x}=1.53)$ and improved access to new technology $(\bar{x}=1.53)$ tiled at the second position while training and provision of information $(\bar{x}=1.50)$ ranked $5^{\text {th }}$. The result of this study implies that though respondents derived array of benefits from WAAPP, these benefits were not considered satisfying by all fisherfolk. Benefits associated with finance were considered low as found in this study. Notwithstanding, WAAPP has brought positive changes into the life of people in the area and it has contributed to their economy in term of benefits derived from the programme as indicated the result in Table 3. 
Creative Commons User License: CC BY-NC-ND

Abstracted by: EBSCOhost, Electronic Journals Service (EJS),

Google Scholar, Journal Seek, Scientific Commons,

Food and Agricultural Organization (FAO), CABI and Scopus
Journal of Agricultural Extension

Vol. 26 (1) January, 2022

ISSN(e): 24086851; ISSN(Print); 1119944X

http://journal.aesonnigeria.org

http://www.ajol.info/index.php/jae

Email: editorinchief@aesonnigeria.org

http://eoi.citefactor.org/10.11226/v26i1

\begin{tabular}{llll}
\hline Table 3: Benefits derived from WAAPP & & & \\
\hline Benefits & Mean & SD & Rank \\
\hline Provision of advice & $1.59^{*}$ & 1.16 & $1^{\text {st }}$ \\
Promotion of local skills & $1.53^{*}$ & 0.86 & $2^{\text {nd }}$ \\
Improved household food security & $1.53^{*}$ & 0.89 & $2^{\text {nd }}$ \\
Improved access to new technology & $1.53^{*}$ & 0.91 & $2^{\text {nd }}$ \\
Training and provision of information & $1.50^{*}$ & 0.90 & $5^{\text {th }}$ \\
Provide effective linkage with customers & 1.47 & 0.94 & $6^{\text {th }}$ \\
Improvement in respondents' capacity & 1.38 & 0.87 & $7^{\text {th }}$ \\
Increased commodity output & 1.38 & 2.11 & $7^{\text {th }}$ \\
Meeting family needs with ease & 1.32 & 0.86 & $9^{\text {th }}$ \\
Creation of job opportunities & 1.21 & 0.85 & $10^{\text {th }}$ \\
Improve social stability & 1.18 & 0.64 & $11^{\text {th }}$ \\
More effective extension services & 1.15 & 0.77 & $12^{\text {th }}$ \\
Market accessibility & 1.09 & 0.84 & $13^{\text {th }}$ \\
Ability to pay school fees & 1.06 & 0.80 & $14^{\text {th }}$ \\
Improved my access to credit facility in fish & & & \\
farming business & 1.00 & 0.74 & $15^{\text {th }}$ \\
\hline
\end{tabular}

Source: Field Survey, 2021, Agreed (mean $\geq 1.50$ )

\section{Constraints Faced by the West Africa Agricultural Productivity Programme}

The result from Table 4 reveals that inadequate capital $(\bar{x}=2.35)$ and high cost of input $(\bar{x}=2.15)$ were perceived as main constraint. This shows that differential financial capability of respondents in the study area might put respondents with low financial capability at a disadvantage during execution of programmes. Inadequate finance and high cost of input such as fish seeds can limit the potential benefits that would have accrued to respondents from programmes that had bearing with their enterprise. Thus, financial capability of beneficiaries can be said to be one of the major determinants of programme sustainability. This also collaborates lqra, Chauhan, Akansha and Priyanka (2018) report that most fish farmers in rural areas are still constrained to meet their financial needs of growing fishing business due to high interest rate and exploitative terms and conditions regarding the disposal of loan. Inadequate extension agents $(\bar{x}=1.09)$, uncertainty of result $(\bar{x}=1.71)$, gender bias $(\bar{x}=1.68)$ and complexity of programme $(\bar{x}=1.26)$ among others were not seen as serious constraints to the programme. This shows that programme was handled with adequate and competent extension agent with good results, gender sensitive and simple. The results of this study shows that participants were not faced with many challenges except financial aspects. 
Creative Commons User License: CC BY-NC-ND

Abstracted by: EBSCOhost, Electronic Journals Service (EJS), Google Scholar, Journal Seek, Scientific Commons,

Food and Agricultural Organization (FAO), CABI and Scopus
Journal of Agricultural Extension

Vol. 26 (1) January, 2022

ISSN(e): 24086851; ISSN(Print); 1119944X

http://journal.aesonnigeria.org

http://www.ajol.info/index.php/jae

Email: editorinchief@aesonnigeria.org

http://eoi.citefactor.org/10.11226/v26i1

\begin{tabular}{llll}
\hline \multicolumn{4}{l}{ Table 4: Constraints encountered by the recipient during WAAPP } \\
\cline { 2 - 4 } & Mean & SD & Rank \\
\hline Constraints items & $2.35^{\star}$ & 0.45 & $1^{\text {st }}$ \\
Inadequate capital & $2.15^{\star}$ & 0.50 & $2^{\text {nd }}$ \\
High cost of input & 1.09 & 0.57 & $3^{\text {rd }}$ \\
Inadequate extension agents & 1.71 & 0.61 & $3^{\text {rd }}$ \\
Uncertainty of result & 1.68 & 0.87 & $5^{\text {th }}$ \\
Gender bias & 1.65 & 0.78 & $6^{\text {th }}$ \\
Time management & 1.65 & 0.87 & $6^{\text {th }}$ \\
Lack of technical know-how & 1.56 & 0.56 & $8^{\text {th }}$ \\
Lack of support for farmers & & & \\
by programme provider & 1.47 & 0.55 & $9^{\text {th }}$ \\
Professional elitism & 1.44 & 0.52 & $10^{\text {th }}$ \\
Lack of interest & 1.32 & 0.45 & $11^{\text {th }}$ \\
Cultural believes & 1.26 & 0.36 & $12^{\text {th }}$ \\
Complexity of programme
\end{tabular}

Source: Field Survey, 2021, Agreed (mean $\geq 2.00$ )

\section{Conclusion and Recommendations}

Respondents benefitted from the WAAPP programme, as they considered advisory services, effective linkage with customers, improved household food security, improved access to new technology and promotion of local skills to be high benefits among others. About half of the fisher folk were severely constrained by inadequate capital to sustain the projects activities. Programme implementers should always provide farmers with soft loans after programmes to procure some inputs and allow them to commit their resources to the programme in order to sustain it. Adequate extension agents should be available to guide and help farmers proffer solution to their problems.

\section{References}

Babatunde, A., Deborah, R.A., Gan, M and Simon, T. (2021). Aquaculture in Africa: A comparative review of Egypt, Nigeria, and Uganda Vis-à-vis South Africa. Fisheries Science and Aquaculture, 29(2).

Christian, L (2020). Impact of Selected Agricultural Policies and Intervention Programmes in Nigeria- 190 till 2020. Retrieved from www.igglobal.com

George, I (2017). Rural Development in Nigeria Since Independence. Retrieved from www.legit.ng

Iqra, N., Chauhan R.S., Akansha, K and Priyanka, A. (2018). Role of credit for the upliftment of the fisheries sector. International Journal of fisheries and aquatic studies, 6(2):0104.

Josef, B. and Jiri, S. (2019). The other disadvantaged neighbourhood: Income related effects of living in rural peripheries. Housing studies (34)6. Pp.946-973 
Creative Commons User License: CC BY-NC-ND

Abstracted by: EBSCOhost, Electronic Journals Service (EJS), Google Scholar, Journal Seek, Scientific Commons,

Food and Agricultural Organization (FAO), CABI and Scopus

http://eoi.citefactor.org/10.11226/v26i1
Journal of Agricultural Extension

Vol. 26 (1) January, 2022

ISSN(e): 24086851; ISSN(Print); 1119944X

http://journal.aesonnigeria.org

http://www.ajol.info/index.php/jae

Email: editorinchief@aesonnigeria.org

Ndem, J.U and Elom, O (2016). Management skills in fish farming needed by retired civil and public servants for sustainable income in Eboyi State. Journal of biology, Agriculture and Healthcare, 6(4)

Nwabeze, G.O.; Faleke, S.; Tanko, M.; Malgwi, Y. (2019). Strategies use by smoked fish marketers in Kainji Lake Basin, Nigeria. Journal of Agricultural Extension, 23(1):5465.

Obeta, M and Chukwudike, U. (2020). Review Nigerian Programmes for modernization from 1985-2018; Success or Failure. (3). Pp 97-116

Obiero, K.O., Waidbacher, H., Nyawanda, B.O. et al. (2019). Predicting Uptake of Aquaculture Technologies among Smallholder Fish Farmers in Kenya. Aquaculture International (27) 1689-1707

Olaleye, Y.L. (2019). Social Mobilization and Community Participation in Development Programmes. Educational Theory and Practice across Disciplines. University of Ibadan. pp.389-408.

Omeje, J.E., Sule, A.M and Aguihe, E.O. (2020). An Assessment of Aquaculture Table-Size Fish Farmers Activities in Kainji Lake Basin, Nigeria. Journal of Tropical Agriculture, Food, Environment and Extension, 19 (2):36-40

Shibani, A (2016). An investigation into training needs for technical staff within Libyan Industrial Companies. A thesis submitted to Nottingham Trent University for Degree of Doctor of Philosophy.

Teddy, C.L. (2017). Determinants of fishermen income in regency of West Serm, Maluku. Ekonimika Juurnal Ekonomi, 11(1).

West Africa Agricultural Productivity Programme Official Site (2017). Retrieved from info@waapp.gov.ng. 